\title{
Healthy efficacy of Nostoc commune Vaucher
}

\author{
Zhuoyu $\mathbf{L i}^{1,2,3}$ and Min Guo ${ }^{1,2,3}$ \\ ${ }^{1}$ College of Life Science, Shanxi University, Taiyuan 030006, China \\ ${ }^{2}$ Institute of Biotechnology, The Key Laboratory of Chemical Biology and Molecular Engineering of Ministry of Education, \\ Shanxi University, Taiyuan 030006, China \\ ${ }^{3}$ Institute of Biomedical Sciences, Shanxi University, Taiyuan 030006, China \\ Correspondence to: Zhuoyu Li, email: Izy@sxu.edu.cn
}

Keywords: Nostoc commune Vaucher; composition; functional food; human health

Received: August 10, 2017 Accepted: October 28, 2017 Epub: December 22, 2017 Published: March 06, 2018

Copyright: Li et al. This is an open-access article distributed under the terms of the Creative Commons Attribution License 3.0 (CC BY 3.0 ), which permits unrestricted use, distribution, and reproduction in any medium, provided the original author and source are credited.

\section{ABSTRACT}

\begin{abstract}
Nostoc commune Vaucher, a macroscopic cyanobacterium, has long been appreciated as a healthy food and traditional medicine worldwide. Accumulated evidence has demonstrated that it possesses a wide range of remarkably protective physiological and pharmacological activities, largely based on animal and in vitro studies. In this review, we summarise and update evidence regarding the chemical composition and nutritional characteristics of Nostoc commune Vaucher, and comprehensively discuss the recent studies on the antioxidative, anti-inflammatory, anti-carcinogenic and immune regulation properties of Nostoc commune Vaucher and Nostoc commune Vaucher-derived extracts. The available results demonstrate the potential of it to act as a functional food for the amelioration of human associated diseases. More details from human clinical trials should be a matter of further investigation.
\end{abstract}

\section{INTRODUCTION}

Nostoc commune Vaucher (N. commune for short), also known as Nostoc commune, is a macroscopic bluegreen algal species, which is a member of the genus Nostoc (Figure 1A) [1]. Notably, it is easily confused with two other species: Nostoc flagelliforme and Nostoc sphaeroides Kütz, especially in primary exploration and determination [2-4]. It often forms visually extended mucilaginous layer colonies on soil and is commonly found on stones and mud in freshwater systems [4-6]. When wet, $N$. commune is bluish green, olive green, or brown in appearance; however, under dry conditions, it becomes an inconspicuous brownish mat (Figure 1B) [2]. Amazingly, colonies of $N$. commune, which are naturally subjected to regular cycles of desiccation and hydration, can retain viability for more than 100 years upon desiccation $[7,8]$. $N$. commune has been found to be distributed in tropical soil, temperate zones, and both northern and southern polar zones $[9,10]$. It has been reported and consumed in many countries and regions especially in Asia. People in some districts of China have widely and traditionally utilized this alga as a food delicacy or ingredient in Chinese medicine since the Eastern Jin Dynasty (317-420 AD), as recorded in the Compendium of Materia Medica (Bencao Gangmu) $[2,6,10,11]$.

Cyanobacteria have been proven to be an extremely valuable source of natural drugs and agents for developing not only medicines, but also functional foods for disease prevention and health promotion $[12,13]$. Considerable attention has therefore been devoted to the development and utilization of more effective and non-toxic novel alternatives of natural origin. Currently, there is a sizable body of literature demonstrating $N$. commune and $N$. communederived extracts' ability to develop anti-inflammatory effects, including anti-infectious and antibacterial activity (Table 1), antioxidative prosperities (Table 2), anti-cancer activity, immunomodulation (Table 3 ) and serum cholesterol reduction. The difference, even diversity, obtained from different studies could be due to the orientation of $N$. commune and experimental methods, as well as the determination and analysis of the measurement results. Unfortunately, to date, the colonies of $N$. commune available in present studies are mainly field materials harvested from natural localities in contrast to limited information on the artificial culturing [5]. However, with the recent development of technology and equipment for culturing, it has become possible to obtain a sufficient sample to 


\begin{tabular}{|c|c|c|c|}
\hline & Bioactives & Key effects & Ref. \\
\hline $\begin{array}{l}\text { petroleum ether, } \\
\text { acetylacetic ester, } \\
\text { acetone, ethanol, } \\
\text { carbinol \& aqueous } \\
\text { extracts }\end{array}$ & & $\begin{array}{l}\text { 1. Lower polar ethyl acetate and acetone extracts exhibited potent antibacterial } \\
\text { activity against } P \text {. aeruginosa, compared to these of Eschenchia coil, } \\
\text { Ahernaria alternate, Peniicillium sp and Trichothecium roseum. } \\
\text { 2. Higher polar methanol and ethanol extracts exhibited potent antibacterial } \\
\text { activity against Alternaria altemata, Peniicillium sp and Trichethecium } \\
\text { roseum, compared to these of Eschenchia coil, P. aeruginosa and Ahernaria } \\
\text { alternate. }\end{array}$ & {$[28]$} \\
\hline \multirow[t]{2}{*}{ methanol extracts } & & $\begin{array}{l}\text { 1. Obvious inhibition growth of Escherichia coli, Staphylococcus aureus, } \\
\text { Bacillus subtilis, Monilia albican and Serratia marcescens (MIC: } 1.5-1.0 \\
\mathrm{mg} / \mathrm{mL} \text { ). }\end{array}$ & [29] \\
\hline & & $\begin{array}{l}\text { 1. Significant antibacterial activity against Bacillus subtilis. } \\
\text { 2. No effect against Salmonella arizonae and Proteus mirabilis. }\end{array}$ & {$[30]$} \\
\hline $\begin{array}{l}\text { fat-soluble } \\
\text { compositions }\end{array}$ & & $\begin{array}{l}\text { 1. Inhibitory effects against six strains: Escherichia coli (MIC: } 64 \mu \mathrm{g} / \\
\mathrm{mL})>\text { Staphylococcus aureus }>\text { Bacillus subtilis }>\text { Aspergillus nigere }> \\
\text { Saccharomyces cerevisiae }>\text { Pseudomonas stutzeri. }\end{array}$ & {$[31]$} \\
\hline \multirow[t]{2}{*}{ diterpenoid } & Noscomin & $\begin{array}{l}\text { 1. Antibacterial activity against Staphylococcus epidermidis (MIC } 8 \text { ppm), } \\
\text { Bacillus cereus (MIC } 32 \mathrm{ppm} \text { ), and Escherichia coli (MIC } 128 \mathrm{ppm}) \text {. }\end{array}$ & {$[23]$} \\
\hline & Comnostins A-E & $\begin{array}{l}\text { 1. Comnostin C had a MIC value for Escherichia coli equal to tetracycline, and } \\
\text { comnostin E for Staphylococcus epidermidis equal to chloramphenicol. } \\
\text { 2. Moderate antibacterial activity of comnostins A-E against Bacillus cereus, } \\
\text { comnostins A-D against S. epidermidis, and comnostins A, B, and D against } \\
\text { E. coli. }\end{array}$ & {$[24]$} \\
\hline diterpenoid & & $\begin{array}{l}\text { 1. Selective potent antibacterial activity against Staphylococcus epidermidis } \\
\text { equal to chloramphenicol (MIC } 4 \mathrm{ppm} \text { ). } \\
\text { 2. Moderate antibacterial activity against Bacillus cereus (MIC } 128 \mathrm{ppm} \text { ). }\end{array}$ & {$[25]$} \\
\hline anthraquinone & & $\begin{array}{l}\text { 1. Moderate antibacterial activity against Staphylococcus epidermidis and } \\
\text { Bacillus cereus (MIC } 32 \mathrm{ppm} \text { ). }\end{array}$ & {$[25]$} \\
\hline indane derivative & & $\begin{array}{l}\text { 1. Moderate antibacterial activity against Staphylococcus epidermidis (MIC } 128 \\
\text { ppm) and Bacillus cereus (MIC } 64 \mathrm{ppm} \text { ). }\end{array}$ & {$[25]$} \\
\hline \multirow[t]{3}{*}{ polysaccharides } & & $\begin{array}{l}\text { 1. Dose dependent inhibited growth of Escherichia coli, Anthrax bacillus and } \\
\text { Staphylococcus aureus. }\end{array}$ & {$[65]$} \\
\hline & & $\begin{array}{l}\text { 1. Inhibition of the growth of Escherichia coli and Bacillus subtilis (MIC:150- } \\
250 . \mu \mathrm{g} / \mathrm{mL} \text { ). }\end{array}$ & {$[46]$} \\
\hline & & $\begin{array}{l}\text { 1. Potent antibacterial activity against Escherichia coli (MIC: } 50 \mu \mathrm{g} / \mathrm{mL} \text { ), } \\
\text { Bacillus subtilis (MIC: } 50 \mu \mathrm{g} / \mathrm{mL} \text { ) and Serratia marcescens (MIC: } 25 \mathrm{mg} / \\
\mathrm{mL} \text { ). } \\
\text { 2. Significant antifungal activity against Aspergillus nigere and Candida albicans } \\
\text { (MIC: } 100 \mathrm{mg} / \mathrm{mL} \text { ). }\end{array}$ & {$[32]$} \\
\hline total flavonoids & & $\begin{array}{l}\text { 1. Dose dependent antibacterial activity against Escherichia coli and } \\
\text { Staphylococcus aureus. } \\
\text { 2. Dose dependent antifungal activity against Aspergillus nigere and Candida } \\
\text { albicans. }\end{array}$ & [34] \\
\hline lipopeptide & Nostofungicidine & 1. Potent antifungal activity against Aspergillus candidus (MIC: $1.6 \mu \mathrm{g} / \mathrm{mL}$ ). & {$[33]$} \\
\hline heteroglycan & Nc-5-s & $\begin{array}{l}\text { 1. Less secretion of IL- } 6 \text { and more of IL-10 in LPS-stimulated human THP-1 } \\
\text { monocytes. } \\
\text { 2. Anti-inflammatory response through the ERK } 1 / 2 \text { pathway and/or the Akt/ } \\
\text { PI3K pathway. }\end{array}$ & {$[13]$} \\
\hline indole alkaloid & $\begin{array}{l}\text { Reduced- } \\
\text { scytonemin }\end{array}$ & $\begin{array}{l}\text { 1. Suppression LPS/IFN } \gamma \text {-induced NO production in murine macrophage RAW264 } \\
\text { cells by inducing HO-1 expression via the Nrf2/ARE pathway. }\end{array}$ & {$[8]$} \\
\hline b-ionone derivatives & $\begin{array}{l}\text { Nostocionone and } \\
\text { its derivatives, } \\
\text { NostD3 }\end{array}$ & $\begin{array}{l}\text { 1. Significant inhibition of Propionibacterium acnes growth. } \\
\text { 2. Suppression heat-killed NO production through decreased iNOS in murine } \\
\text { macrophage RAW264 cells (RCB 0535), following inactivation of NF- } \kappa B \text {. }\end{array}$ & {$[35]$} \\
\hline
\end{tabular}

Abbreviations: PI3K, phosphoinositide 3-kinase; NO, nitric oxide; HO, hemeoxygenase; iNOS, inducible nitric oxide synthase. 


\begin{tabular}{|c|c|c|c|}
\hline & Bioactives & Key effects & Ref. \\
\hline \multirow[t]{2}{*}{ polysaccharides } & & $\begin{array}{l}\text { 1. } \mathrm{O}_{2}^{--} \text {scavenging capacity value was higher by } 54.8 \% \text { and } 103.7 \% \text {, } \\
\text { respectively, compared to Nostoc flagelliforme and Nostoc sphaeroides } \\
\text { Kütz. }\end{array}$ & {$[43]$} \\
\hline & & $\begin{array}{l}\text { 1. Increase the antioxidase activity in Caenorhabditis elegans. } \\
\text { 2. Decrease the lipid peroxidation level in Caenorhabditis elegans. } \\
\text { 3. Paraquat-induced oxidative damage reducation in Caenorhabditis } \\
\text { elegans. }\end{array}$ & {$[6]$} \\
\hline total flavonoids & & $\begin{array}{l}\text { 1. Higher antioxidative ability than those of polysaccharides and fat- } \\
\text { soluble components. }\end{array}$ & {$[49,51]$} \\
\hline $\begin{array}{l}\text { glycosylated } \\
\text { mycosporine-like } \\
\text { amino acids (MAA) }\end{array}$ & 1050-Da MAA & $\begin{array}{l}\text { 1. Approximate } 27 \% \text { contribution of the total radical scavenging activity } \\
\text { in the water extract of } N \text {. commune. }\end{array}$ & {$[17]$} \\
\hline
\end{tabular}

conduct more basic research and meet the requirements of industrial-scale applications. In this review, available knowledge regarding the chemical composition and nutritional characteristics of $N$. commune and the healthy efficacy in human associated diseases is summarised and discussed (Figure 2).

\section{CHEMICAL COMPOSITION AND NUTRITIONAL CHARACTERISTICS}

In spite of a long history of usage in the medicinal cuisine of oriental regions and countries, until approximately 20 years ago, only a limited number of studies have been conducted to verify the chemical composition and implicated functions of $N$. commune. These studies were mainly undertaken by Chinese researchers and reported in Chinese journals.

A

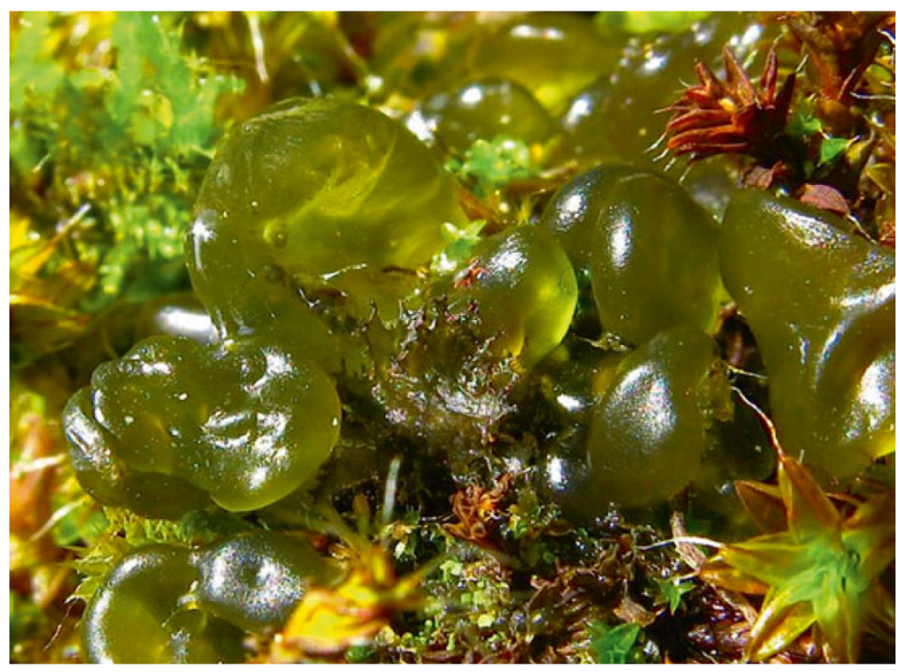

Following the early efforts on the putative health benefits of $N$. commune, recent studies have identified several components, including proteins, peptides (enzymes), amino acids, fatty acids, carbohydrates, vitamins, minerals, and other bioactive chemicals. Proteins, peptides, and free amino acids account for $25 \% \sim 27 \%$ of the dry weight of $N$. commune, and even greater percentage in Nostoc flagelliforme and Laver [10, 14]. The amino acid composition, both protein-bound and free, is considerably diverse, similar to that of commonly consumed mushrooms. For example, it contains all types of essential amino acids for human health, and their proportion is appropriate to meet our needs, indicating that it has a favorable nutritional value $[10,15]$. N. commune consists of $51.12 \%$ carbohydrates [10], including galactose, glucose, trehalose, fructose, xylose and polyhydric alcohol [14]. It should be noted that $N$. commune is dominated by

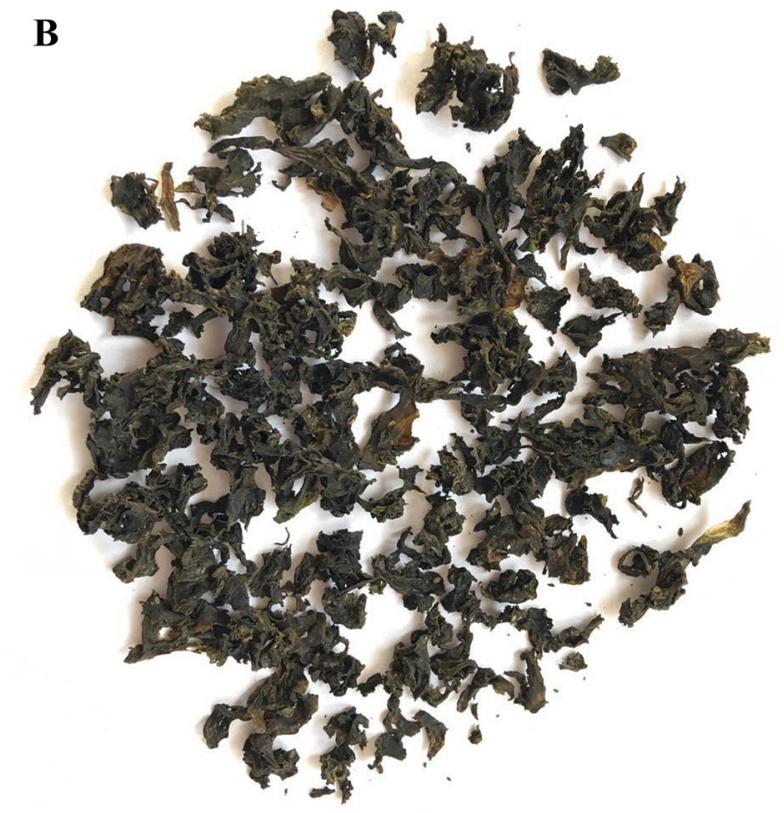

Figure 1: Nostoc commune Vaucher in nature (A) [1] and under dry condition (B). 
Table 3: Anti-carcinogenic and Immunomodulating property of $N$. commune

\begin{tabular}{|c|c|c|c|}
\hline Bioactives & Model & Key effects & Ref. \\
\hline \multicolumn{4}{|c|}{ Anti-carcinogenic property } \\
\hline crude extracts & $\begin{array}{l}\text { A549, human lung epithelium } \\
\text { adenocarcinoma } \\
\text { SMMC-7721, human } \\
\text { hepatocellular carcinoma }\end{array}$ & $\begin{array}{l}\text { 1. Significant inhibition of cell proliferation with } \mathrm{IC}_{50} \text { of } \\
24.79 \text { and } 51.33 \mu \mathrm{g} / \mathrm{mL} \text {, respectively. }\end{array}$ & {$[55]$} \\
\hline reduced-scytonemin & $\begin{array}{l}\text { Human T-lymphoid cell line } \\
\text { Jurkat cells }\end{array}$ & 1. Induction of autophagy by ROS formation & {$[7]$} \\
\hline $\begin{array}{l}\text { synthesized } \\
\text { Nostocionone } \\
\text { derivative }\end{array}$ & $\begin{array}{l}\text { Human T-lymphoid cell line } \\
\text { Jurkat cells }\end{array}$ & $\begin{array}{l}\text { 1. Potently inhibited cell growth more than } \\
\text { Nostocionone. } \\
\text { 2. Inhibited cell apoptosis through mitochondria via the } \\
\text { release of Endo-G. }\end{array}$ & {$[4]$} \\
\hline \multirow[t]{3}{*}{ water stress proteins } & $\begin{array}{l}\text { DLD1, HCT-116, HT-29, and } \\
\text { SW480, } \\
\text { human colon carcinoma }\end{array}$ & $\begin{array}{l}\text { 1. Inhibited cell proliferation with } \mathrm{IC}_{50} \text { of } 0.19 \pm 0.02 \text {, } \\
0.21 \pm 0.03,0.39 \pm 0.05 \text {, and } 0.41 \pm 0.01 \mu \mathrm{g} / \mathrm{mL} \text {, } \\
\text { respectively. } \\
\text { 2. No effect on normal human intestinal epithelial FHC } \\
\text { cells. } \\
\text { 3. Halted the cell cycle by } \mathrm{G}_{1} / \mathrm{S} \text { arrest. } \\
\text { 4. Induced cell apoptosis through caspase-dependent } \\
\text { pathway. }\end{array}$ & [57] \\
\hline & $\begin{array}{l}\text { BALB/c mice with } \\
\text { subcutaneously implanted DLD1 } \\
\text { cells }\end{array}$ & 1. Suppressed tumor after WSP1 treatment & [57] \\
\hline & DLD1, human colon carcinoma & $\begin{array}{l}\text { 1. Increased cell-cell adhesion and reduced cell-matrix } \\
\text { adhesion. }\end{array}$ & [58] \\
\hline $\begin{array}{l}\text { recombinant water } \\
\text { stress proteins } 1\end{array}$ & SW480, human colon carcinoma & $\begin{array}{l}\text { 1. Significant suppression of cell growth. } \\
\text { 2. No effect on normal human intestinal epithelial FHC cells. }\end{array}$ & {$[56]$} \\
\hline \multirow[t]{2}{*}{$\begin{array}{l}\text { extracelluar } \\
\text { polysaccharides }\end{array}$} & $\begin{array}{l}\text { MCF-7, human breast cancer; } \\
\text { DLD1, human colon carcinoma }\end{array}$ & $\begin{array}{l}\text { 1. Significant inhibited cell proliferation with } \mathrm{IC}_{50} \text { of } 67 \\
\text { and } 110 \mu \mathrm{g} / \mathrm{mL} \text {, respectively. } \\
\text { 2. Induced cell apoptosis through intrinsic, extrinsic and } \\
\text { ERS-mediated signaling pathways. }\end{array}$ & [61] \\
\hline & $\begin{array}{l}\text { NCI-H446 \& NCI-H1688, } \\
\text { human small cell lung } \\
\text { cancer }\end{array}$ & $\begin{array}{l}\text { 1. Remarkable suppressed cell migration through } \\
\text { blocking the EMT. } \\
\text { 2. Inhibition of integrin } \beta 1 / \text { FAK signaling through } \\
\text { regulating cell-matrix adhesion. } \\
\text { 3. Blockage of STAT3 nuclear translocation and JAK1 } \\
\text { signaling. }\end{array}$ & [62] \\
\hline \multicolumn{4}{|c|}{ immunomodulating property } \\
\hline oligosaccharides & Sheep erythrocytes & $\begin{array}{l}\text { 1. Strong effect on the complement system by } \\
\text { complement fixation test. }\end{array}$ & {$[11]$} \\
\hline $\begin{array}{l}\text { polysaccharides- } \\
\text { rich extract }\end{array}$ & $\begin{array}{l}\text { Human peripheral blood- } \\
\text { mononuclear cells; U937, } \\
\text { human leukemia; Raw } 264.7, \\
\text { murine } \\
\text { macrophage cells }\end{array}$ & $\begin{array}{l}\text { 1. Effective inhibited cell growth of U937. } \\
\text { 2. Triggered monocytic/ macrophagic differentiation in } \\
\text { U937. } \\
\text { 3. Upregulation of GM-CSF and IL-1 } \beta \text { and } \\
\text { downregulation of IL-6 and IL-17. } \\
\text { 4. Increased NO and superoxide secretion in Raw } 264.7 \text {. }\end{array}$ & [64] \\
\hline
\end{tabular}

Abbreviations: ROS, reactive oxygen species; Endo-G, endonuclease G; ERS, endoplasmic reticulum stress; EMT, epithelialmesenchymal transition program; GM-CSF, granulocyte/macrophage-colony stimulatory factor; NO, nitric oxide. 
extracellular polysaccharides (EPS) ( $\sim 80 \%$ dry weight), and that its composition is being examined and verified $[16,17]$. The fatty acids of $N$. commune are very low, accounting for only $0.21 \%$ of its dry matter [10, 18, 19]. $N$. commune also contains dietary fiber $[5,20]$. In addition, $N$. commune can be characterised by great variety in both the number and type of constitutive minerals, and it is especially enriched with essential elements, such as iron (Fe), zinc ( $\mathrm{Zn})$ and calcium (Ca) ( 4\%o), at significantly higher levels than in Lentinusedodes, Auriculariaauricula and Nostoc flagelliforme [10, 14, 21, 22]. This constitution makes a big difference in the prominent health promotion of $N$. commune through synergistic and supplementary effect with other nutrient molecules [21]. Some vitamins have also been characterised and quantified. For example, the content of vitamin $\mathrm{C}$ is equal to that in the Nostoc flagelliforme [10, 19].

Intriguingly, many phytochemicals and bioactive compounds purified from $N$. commune have been reported and identified, the structures of which are shown in Figure 3. These components could be divided into the following common types: (1) amino acids, fats and lipids (Figure 3A-3D), such as diterpenoid compounds, which are rather uncommon in cyanobacteria [23-25]; (2) carbohydrates (Figure 3E, 3F); (3) aromatic hydrocarbons and heterocyclic compounds (Figure 3G,3H); (4) ketones and quinones (Figure 3I, 3J). Notably, most of compounds mentioned above have been only discovered and identified, and little is known regarding the details of potential functional properties. Taken together, $N$. commune is characterised by its great variety in both the number and type of nutrients, especially rich with various small molecules, comparable to those of Auricularia auricular [10, 17], making it a potential resource for natural functional foods.

It should also be noted that the distribution of these components varies as the cultural factors change during the growth, such as the origin, light, temperature, and nutritional levels. For example, it is unavoidable to mix with weeds and silt when $N$. commune is harvested in the fields [10]. The experimental methods, technology, determination of results and postharvest treatment could also lead to fluctuations and discrepancies $[10,17]$.

\section{ANTI-INFLAMMATORY AND ANTIBACTERIAL PROPERTIES OF $\mathrm{N}$. COMMUNE}

Inflammation is a natural immune response to injury or infection involving excessive production of inflammatory mediators, such as interleukin (IL) family cytokines, nitric oxide (NO), prostaglandin E2 (PGE2), ROS, and RNS, as well as the presence of highly activated inflammatory cells, such as neutrophils, monocytes and macrophages, that if unabated, lead to the development of serious chronic diseases, including cancer, cardiovascular disease, neurodegeneration and metabolic disorders $[1,26]$. Extensive studies have shown that functional foods are appealing alternatives to clinical pharmacological therapies for treating and preventing inflammation and inflammation-related diseases.

Some important insights into the anti-inflammatory activity of $N$. commune were obtained based on cell culture studies. In a study conducted by Itoh et al, reduced

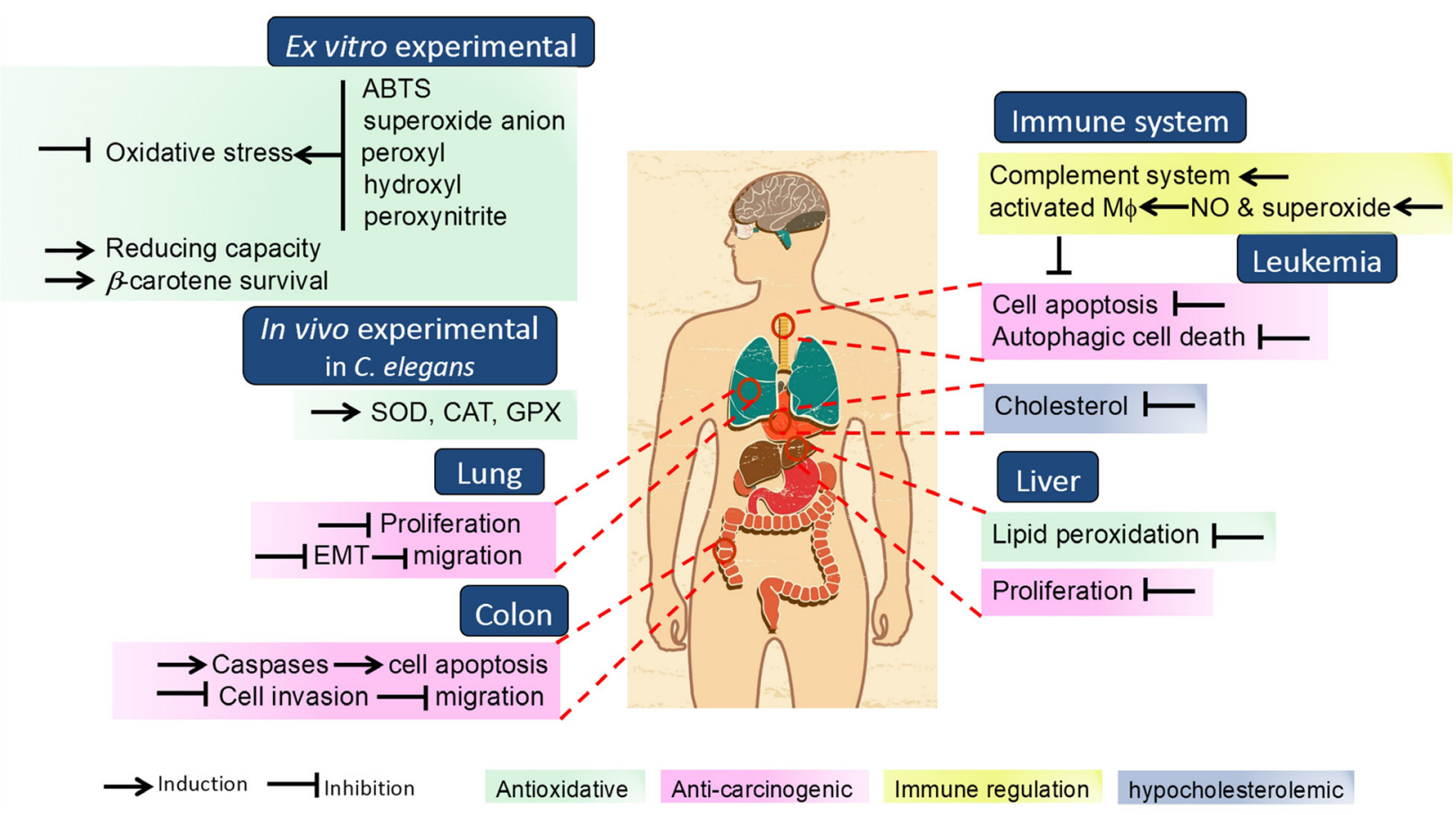

Figure 2: Schematic representation of $N$. commune and $N$. commune-derived extracts regulative properties on human health. 
scytonemin (R-scy) significantly suppressed LPS/IFN $\gamma$ induced NO production in murine macrophage Raw 264.7 cells. Mechanistically, R-scy was found to generate intracellular ROS, and thereby activate p38 MAP kinase and PI3K/Akt. The resultant Nrf2/ARE activation induces HO-1 expression and augments antioxidative activity, resulting in suppression of LPS/IFN $\gamma$-induced inflammatory responses [8]. They also found that nostocionone (Nost) and one of its derivatives (NostD3) significantly inhibit Propionibacterium acnes growth. Furthermore, they investigated the effects and detected that both Nost and NostD3 suppressed heat-killed $P$. acnes-induced nitric oxide (NO) production by suppressing of inducible NO synthase

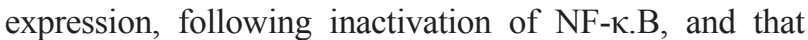
NostD3 showed higher efficacy than Nost [27]. Hardardottir et al. reported that a heteroglycan, designated as Nc-5-s, had anti-inflammatory effects on IL- 6 and IL-10 secretion by THP-1 monocytes primed with interferon-g and stimulated with LPS through the ERK1/2 pathway and/or the Akt/ phosphoinositide 3-kinase pathway [13].

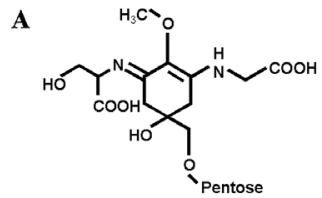

464 Da MAA, Glycosylated derivative of Shinorine<smiles>COC1=C(NCC(=O)O)CC(O)(CO)C(=O)C1=NC(C)C(C)OCCO</smiles>

508Da MAA, Glycosylated derivative of Porphyra-334<smiles>COC1=C(NCC(=O)O)CC(O)(CO[Al])C(=NC(C)C(C)O)C1OC</smiles>

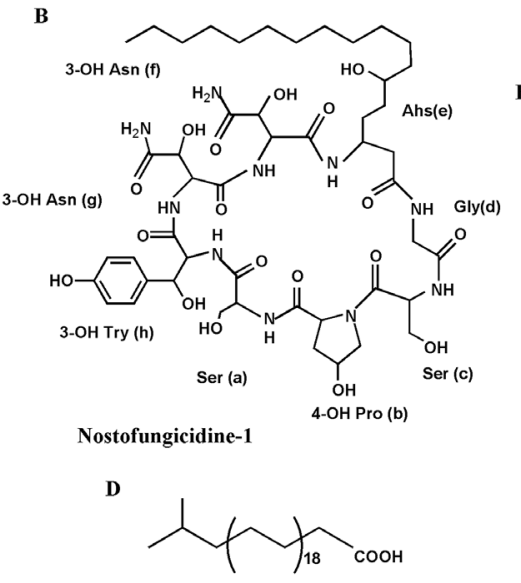

E

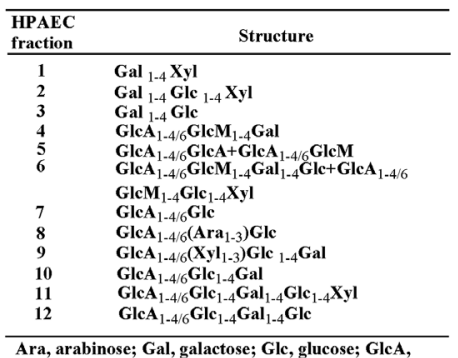
glucuronic acid; GleM, 2-O-methylglucose; $\mathrm{Xyl}$, xylose

478Da MAA, Glycosylated derivative of Porphyra-334

C

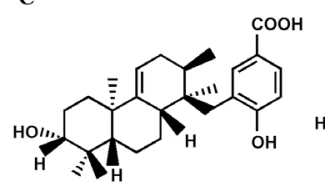

Noscomin

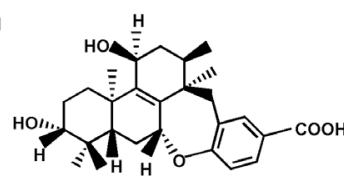

diterpenoid derivative

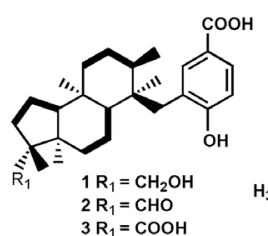

$3 \mathrm{R}_{1}=\mathrm{COOH}$

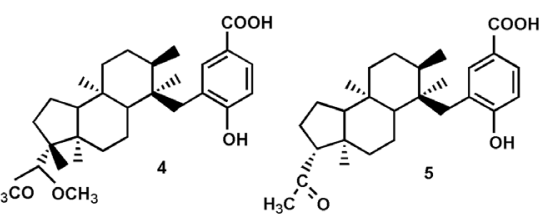

1-5: Comnostins A-E

F

$$
\begin{aligned}
& \text { 1: }[4) 2-\mathrm{OMe}-\beta-\mathrm{Glc} p \mathrm{~A}-(1-4)-\beta-\mathrm{Xyl} p-(1-3)-\beta-\mathrm{Glc} p-(1-4)-\beta-\mathrm{Arap}-(1-] \mathrm{K} \\
& \text { 1a: }[4) 2-\mathrm{OMe}-\beta-\mathrm{Glc} p \mathrm{~A}-(1-4)-\beta-\mathrm{Xyl} p-(1-3)-\beta-\mathrm{Glc} p-(1-4)-\beta-\operatorname{Arap}-(1-] \mathrm{n} \\
& \text { 2-OMe- } \alpha-\operatorname{Araf}-(1-3)
\end{aligned}
$$

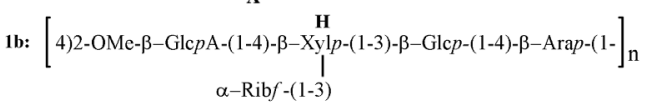

$$
\begin{aligned}
& \mathrm{B} / \mathrm{C}
\end{aligned}
$$

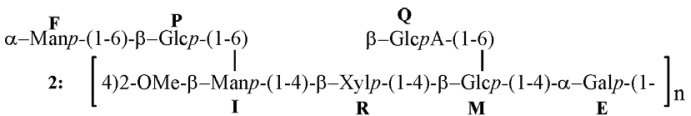

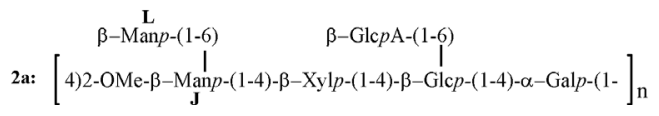

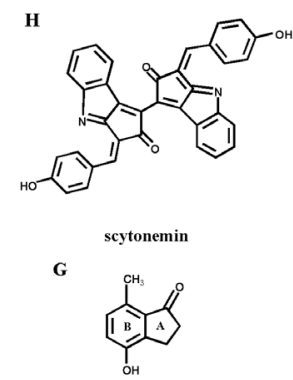

4-hydroxy-7-methylindan-1-one

$\mathbf{J}$

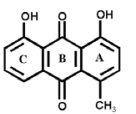

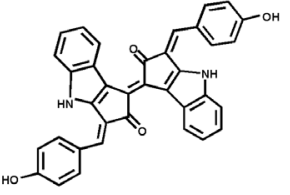

reduced scytonemin

$N$-acetyltryptamine

$N$-(p-coumaroyl)-tryptamine

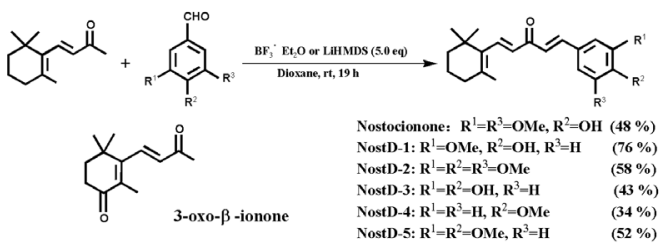

Figure 3: Chemical structures of common bioactive compounds from $\boldsymbol{N}$. commune. (A) Structure of glycosylated mycosporinelike amino acids [17, 49]. (B) Structure of an antifungal lipopeptide [33]. (C) Structure of diterpenoid derivatives which is uncommon in cyanobacteria [23-25]. (D) Structure of a long chain fatty acid [18]. (E) Structure of oligosaccharides isolated after weak acid hydrolysis of the acidic polysaccharide [11]. (F) Structure of Nc-5-s, a complex heteroglycan, composed of repeating units of 1, 1a, 1b and 2 and 2a in molar ratio of $(10: 25: 50: 5: 10)$ [13, 66]. (G) Structure of an indane derivative [25]. (H) Structure of indole alkaloids [7, 8, 27, 41]. (I) Structure of $\beta$-ionone derivatives [4, 27, 41]. (J) Structure of an anthraquinone derivative [25]. 
Recent studies have proved the antibacterial and antifungal properties of $N$. commune and $N$. communederived extracts. Bi et al. compared the antibacterial and antifungal properties of various extracts from $N$. commune, including petroleum ether, acetylacetic ester, acetone, ethanol, carbinol and aqueous extracts, and found that lower polarity ethyl acetate and acetone extracts exhibit potent antibacterial activity against $P$. aeruginosa, compared to those of Eschenchia coil, Ahernaria alternate, Peniicilliumsp and Trichotheciumroseum, whereas higher polarity methanol and ethanol extracts exhibit potent antibacterial activity against Alternariaaltemata, Peniicilliumsp and Trichetheciumroseum, compared to those of Eschenchia coil, P. aeruginosa and Ahernaria alternate [28]. Hassan and $\mathrm{Li}$ et al. found that the methanol extract from $N$. commune showed obvious inhibition of the growth of Escherichia coli, Staphylococcus aureus, Bacillus subtilis, Moniliaalbican and Serratiamarcescens (MIC: 1.5-1.0 mg/mL) [29, 30]. Yang et al. evaluated the antibacterial activity of the fatsoluble component and observed that it exerted better inhibitory effects against Escherichia coli (MIC: $64 \mu \mathrm{g} /$ $\mathrm{mL}$ ) [31]. In a continuing investigation, Sticher et al. reported several diterpenoid (Noscomin and Comnostins A-E), anthraquinone and indane derivatives, and found that Noscomin, Comnostin E and another diterpenoid had MIC values for Staphylococcus epidermidis equal to those of chloramphenicol, and the MIC of Comnostin C for Escherichia coli was equal to that of tetracycline. Other compounds only possess moderate antibacterial activity [23, 25]. Polysaccharides were shown to potently inhibit Escherichia coli and Bacillus subtilis (MIC: $50 \mu \mathrm{g} /$ $\mathrm{mL}$ ) by Li et al [32]. In addition, the antifungal activity of $N$. commune extracts was also demonstrated, including polysaccharides, total flavonoids and Nostofungicidine, which showed significant inhibition against Aspergillus nigere, Candida albicans and Aspergillus candidus [32-34].

The mechanism of the antibacterial action of $N$. commune and $N$. commune-derived extracts has remained unelucidated, although $N$. commune has been proved to be a powerful anti-bacterial and antifungal agent in vitro. Further research in animals and humans is therefore warranted to ascertain whether $N$. commune could attenuate inflammation or inflammation-associated diseases.

\section{ANTIOXIDATIVE PROPERTIES OF $N$. COMMUNE}

Oxidative stress is provoked by a number of free radicals, including oxygen free radicals, ROS, and reactive nitrogen species (RNS), which are products of multiple cellular metabolic processes [35-37]. Normally, oxidative stress could be eliminated by endogenous antioxidases. However, once redox homeostasis is in disorder, radicals over-accumulate, resulting in DNA damage and inactivation of proteins and enzymes, which sequentially contribute to the onset and progression of mutagenesis, aging, inflammation, carcinogenesis and cardiovasculardiseases [36-39]. Considerable attention has therefore been devoted to the development and utilization of more effective non-toxic antioxidants of natural origin to improve human health.

The antioxidative capacity of the $N$. communederived extract was established in vitro based on its reducing capacity, the $\beta$-carotene survival rate and scavenging of 2,2'-azino-bis(3-ethylbenzothiazoline-6sulfonic acid; ABTS) radical, superoxide anions $\left(\mathrm{O}_{2}{ }^{--}\right)$, $\mathrm{Fe}^{2+}$, peroxyl radicals, hydroxyl radicals, and peroxynitrite [40-50]. Compared to Nostoc flagelliforme and Nostoc sphaeroides Kütz, the $\mathrm{O}_{2}^{--}$scavenging capacity value of polysaccharides from $N$. commune was higher by $54.8 \%$ and by $103.7 \%$, respectively [42]. Meanwhile, Huang et al. further detected that the polysaccharide can increase antioxidase activity, decrease the lipid peroxidation level, and reduce paraquat-induced oxidative damage using the model animal Caenorhabditis elegans [6]. In turn, it has been proved that the antioxidative ability of total flavonoids is higher than those of polysaccharides and fatsoluble components by Diao et al. [48, 50].

In addition, several glycosylated mycosporine-like amino acids (MAA) have been purified and identified from $N$. commune, such as porphyra-334 (346 Da), pentosebound shinorine (464 Da), 7-O-(b-arabinopyranosyl)porphyra-334 (478 Da), hexose-bound porphyra-334 (508 Da) and 1050-Da [17, 49]. When Sakamoto et al. directly monitored the decrease of ABTS radicals by $\mathrm{ESR}$, the activity of the 478-Da MAA ( $\left.\mathrm{IC}_{50}: 185 \mathrm{mM}\right)$ was equivalent to that of Trolox (used for a standard with $\mathrm{IC}_{50}$ : $182 \mathrm{mM}$ ), and the 1050-Da MAA ( $\left.\mathrm{IC}_{50}: 55 \mathrm{mM}\right)$ showed higher activity than did Trolox, contributing approximately $27 \%$ of the total radical scavenging activity in a water extract of $N$. commune [17]. MAAs are UV absorbing pigments and 478-Da MAA has an absorption maximum at $335 \mathrm{~nm}$. In particular, the 1050-Da MAA with Amax at 312 and $340 \mathrm{~nm}$, consists of two distinct chromophores of 3-aminocyclohexen-1-one and 1,3-diaminocyclohexen as well as two pentose and hexose sugars [17]. UVA (400-320 $\mathrm{nm}$ ) radiation, which contributes to up to $95 \%$ of the total UV exposure, is not absorbed by DNA but it is a strong oxidant and considered the most important source of oxidative stress [51]. Therefore, we structurally speculate MAAs are likely to protect against UV radiation by scavenging ROS, including excited singlet oxygen and triplet state molecules [51].

The reports described above demonstrate that $N$. commune possess beneficial and effective antioxidative activity, and identify compounds that are potentially responsible for these effects. However, it should be mentioned that different or even contrary outcomes from a type of extract obtained in the above-mentioned studies could be due to different methods and reaction systems for testing $[44,45]$. In addition, we should note that the 
orientation and location of $N$. commune may contribute to the discrepancy $[42,47]$.

\section{ANTI-CARCINOGENIC AND IMMUNOMODULATORY PROPERTIES OF N. COMMUNE}

Cancer is still one of the deadliest diseases and a major threat to human health and life worldwide. Current projections imply that the incidence of cases will increase by $70 \%$ over the next twenty years, further highlighting the critical need to identify safe and effective approaches to managing cancer [52]. Tumour metastasis is the most destructive stage of cancer progression and the leading cause of cancer-related death. It is a complex and multistep event, wherein cancer cells leave the site of the primary tumour and disseminate to distant sites in the body $[53,54]$. Taking into account the serious side effects and toxicity of conventional chemotherapeutic agents, a great deal of researches has focused on discovering anticancer alternatives from natural resources for the development of effective and safe therapeutics.

In the early stage of $N$. commune research, it was believed that $N$. commune had anti-cancer activity, which was widely publicized. Not until 2007, was its anti-cancer activity successfully proved and verified by precise scientific experiments conducted by Zhang et al. The crude extract from $N$. commune was shown to significantly inhibit the proliferation of A549 and SMMC-7721 cells with $\mathrm{IC}_{50}$ of 24.79 and $51.33 \mu \mathrm{g} / \mathrm{mL}$, respectively [43]. Recently, studies have demonstrated that a small molecule designated reduced scytonemin (R-scy) isolated from $N$. commune may be able to induce autophagic cell death in human T-lymphoid line Jurkat cells. These studies further examined the mechanisms where cells treated with R-scy produced large amount of ROS, leading to mitochondrial dysfunction [7]. In continuation of their studies, a compound, named Nostocionone (Nost), was isolated from $N$. commune, and its derivatives (NostDs) were synthesised. Interestingly, NostD3 showed more potent inhibition of cell growth than Nost in Jurkat cells. Mechanistically, NostD3 was found to potentiate cell apoptosis through promotion of the intrinsic apoptotic signal, accompanied by the release of endonuclease $G$ (Endo-G) from mitochondria [4]. Subsequently, Guo et al. reported that the growth of DLD1 human colon cancer cells was more significantly blocked by water stress proteins (WSPs), with an $\mathrm{IC}_{50}$ of $0.19 \pm 0.02 \mu \mathrm{g} / \mathrm{mL}$, through a caspase-dependent pathway than other cell lines, including HCT-116, HT-29, and SW480. Meanwhile, WSP1 has also been shown to possess interference in $\mathrm{G}_{1} / \mathrm{S}$ arrest. Additionally, they also observed similar results in vivo in which $\mathrm{BALB} / \mathrm{c}$ mice were subcutaneously implanted with DLD1 cells. Moreover, treatment with recombinant WSP1 (rWSP1) clearly reduced the proliferation of SW480 cells. Besides, they suggested that
WSP1 exhibits anti-metastasis activity by weakening cell invasion of DLD1 cells through upregulating the levels of E-cadherin and reducing $\mathrm{N}$-cadherin, vimentin and integrin $\beta 1$ [55-57]. Polysaccharides have been implicated as major active components of natural drugs and agents, and they always possess strong anti-cancer properties [58, 59]. The results obtained from our study are in agreement with these observations. In our research, polysaccharides from $N$. commune (NVPS) were first shown to exhibit suppression of proliferation of $\mathrm{MCF}-7$ human breast cancer cells and DLD-1 colorectal cancer cells $\left(\mathrm{IC}_{50}=67\right.$ and $110 \mu \mathrm{g} / \mathrm{mL}$, respectively). Further analysis indicated that NVPS-incurred cell growth inhibition was strictly related to apoptosis through intrinsic, extrinsic and endoplasmic reticulum stress (ERS)-mediated apoptotic signalling pathways [60]. We extended our investigation to elucidate anti-metastatic activity of NVPS in human small cell lung cancer cells (NCI-H446 and NCI-H1688). The results showed that NVPS remarkably suppressed cell migration by blocking the epithelial-mesenchymal transition by abating integrin $\beta 1 / F A K$ signalling through enhancing cell-matrix adhesion, increasing E-cadherin expression, and decreasing $\mathrm{N}$-cadherin, vimentin, and MMP-9 expression, which resulted in the blockage of STAT3 nuclear translocation and JAK1 signalling [61].

Immunomodulatory activity has frequently been discussed as an indirect mechanism of anticancer potential $[62,63]$. Generally speaking, $\alpha$-glucan has little bioactivity, and most effective biologically polysaccharides main-chain structures contain $\beta-(1 \rightarrow 3)$ $D$-glucan [64]. In 2000, Paulsen et al found that polysaccharides of $N$. commune from field material were shown to activate the complement system stronger compared with the standard polysaccharide, the acidic one the highest [11]. There is one major thing that all the polymers have in common: the higher amount of 1,3 substituted glucose units [11]. Liao et al. also reported the immunomodulatory potential of the polysacchariderich extract from $N$. commune (NCPS) and found that the immunity of murine macrophage Raw 264.7 cells might be activated by nitric oxide and superoxide secretion and consequently effectively inhibit the growth of human leukemic U937 cells as well as trigger the differentiation of U937 monoblast cells into monocytic/macrophagic lines resulting from the upregulation of GM-CSF and IL-1 $\beta$ as well as the downregulation of IL-6 and IL-17 [65]. Taken together, these studies demonstrated that $N$. commune may have potential as a cancer chemopreventative agent. However, the relationships between the structure and activity are still not fully understood yet.

\section{CONCLUSIONS}

In addition to the broad spectrum of functional properties aforementioned, there are several additional effects of $N$. commune and $N$. commune-derived extracts 
have been reported, such as the hypocholesterolemic function $[5,20]$. Therefore, the available reports may provide evidence that $N$. commune is distributed worldwide, as reviewed here, and is characterised by its great variety in both the number and type of nutrients, especially rich with various small molecules, making it an attractive natural resource treasure. Majority of current studies are concentrated on antioxidative, antiinflammatory and antibacterial properties, rather other activities, providing broad research areas in future. Further research, especially human randomised clinical trials, is vital to ascertain the detailed beneficial effects, bioactivities and molecular mechanisms of $N$. commune and $N$. commune-derived extracts. We believe these efforts will call more attention to the value of $N$. commune on human health, and contribute to the development and application in functional foods and medicines targeted at the prevention and treatment of the mentioned above diseases.

\section{ACKNOWLEDGMENTS AND FUNDING}

Support from the National Natural Science Foundation of China (No. 31770382, 31500630 \& $81603020)$ is gratefully acknowledged.

\section{CONFLICTS OF INTEREST}

None.

\section{REFERENCES}

1. Jain P, Pandey R, Shukla SS. Natural sources of antiinflammation. In: Inflammation: Natural Resources and Its Applications. Springer, India; 2015; 25-133.

2. Potts M. Etymology of the genus name Nostoc (Cyanobacteria). Int J Syst Bacteriol. 1997; 47:584.

3. Wright D, Prickett T, Helm R, Potts M. Form species Nostoc commune (Cyanobacteria). Int J Syst Evol Micr. 2001; 51:1839-1852.

4. Itoh T, Muramatsu Y, Masu M, Tsuge A, Taniguchi M, Ninomiya M, Ando M, Tsukamasa Y, Koketsu M. A synthesized nostocionone derivative potentiates programmed cell death in human T-cell leukemia Jurkat cells through mitochondria via the release of endonuclease G. Nutr Cancer. 2014; 66:1414-1423.

5. Briones-Nagata MP, Martinez-Goss MR, Hori K. A comparison of the morphocytology and chemical composition of the two forms of the cyanobacterium, Nostoc commune Vauch., from the Philippines and Japan. J Appl Phycol. 2007; 19:675-683.

6. Li H, Xu J, Liu Y, Ai S, Qin F, Li Z, Zhang H, Huang $Z$. Antioxidant and moisture-retention activities of the polysaccharide from Nostoc commune. Carbohydr Polym. 2011; 83:1821-1827.
7. Itoh T, Tsuzuki R, Tanaka T, Ninomiya M, Yamaguchi Y, Takenaka H, Ando M, Tsukamasa Y, Koketsu M. Reduced scytonemin isolated from Nostoc commune induces autophagic cell death in human T-lymphoid cell line Jurkat cells. Food Chem Toxicol. 2013; 60:76-82.

8. Itoh T, Koketsu M, Yokota N, Touho S, Ando M, Tsukamasa Y. Reduced scytonemin isolated from Nostoc commune suppresses LPS/IFN $\gamma$-induced NO production in murine macrophage RAW264 cells by inducing hemeoxygenase-1 expression via the Nrf2/ARE pathway. Food Chem Toxicol. 2014; 69:330-338.

9. Whitton A, Potts M. The ecology of cyanobacteria: their diversity in time and space; Kluwer Academic Publishers: Dordrecht, The Netherlands, 2000.

10. Li D, Liu Y. The past decade's researches on Nostoc commune Vaucher in China: a review. Acta Hydrobiol Sin. 2003; 27:408-412.

11. Brüll L, Huang Z, Thomas-Oates J, Paulsen B, Cohen E, Michaelsen T. Studies of polysaccharides from three edible species of Nostoc (Cyanobacteria) with different colony morphologies: structural characterization and effect on the complement system of polysaccharides from Nostoc Commune. J Phycol. 2000; 36:871-881.

12. Singh R, Tiwari S, Rai A, Mohapatra T. Cyanobacteria: an emerging source for drug discovery. J Antibiot (Tokyo). 2011; 64:401-412.

13. Olafsdottir A, Thorlacius GE, Omarsdottir S, Olafsdottir ES, Vikingsson A, Freysdottir J, Hardardottir I. A heteroglycan from the cyanobacterium Nostoc commune modulates LPS-induced inflammatory cytokine secretion by THP-1 monocytes through phosphorylation of ERK1/2 and Akt. Phytomedicine. 2014; 21:1451-1457.

14. Sheng J, Fan H. The applied study and prospect of Nostoc commune. J Guangxi Norm Univ., Nat Sci Ed. 1993; 11:60-63.

15. Li T, Chen G, Suo Y. Characteristic analysis of amino acids of Nostoc commune in Qinghai plateau. Amino Acids Biotic Resour. 2004; 26:6-8.

16. Pereira S, Zille A, Micheletti E, Moradas-Ferreira P, De Philippis R, Tamagnini P. Complexity of cyanobacterial exopolysaccharides: composition, structures, inducing factors and putative genes involved in their biosynthesis and assembly. FEMS Microbiol Rev. 2009; 33:917-941.

17. Matsui K, Nazifi E, Kunita S, Wada N, Matsugo S, Sakamoto T. Novel glycosylated mycosporine-like amino acids with radical scavenging activity from the cyanobacterium Nostoc commune. J Photochem Photobiol B. $2011 ; 105: 81-89$.

18. Temina M, Rezankova H, Rezanka T, Dembitsky VM. Diversity of the fatty acids of the Nostoc species and their statistical analysis. Microbiol Res. 2007; 162:308-321.

19. Yan G, Ji L, Han M, Chen D. Analysis and evaluation of the nutritional components of Nostoc commune Vauch. Acta Nutrimenta Sinica. 2010; 32:97-98. 
20. Hori K, Ishibashi G, Okita T. Hypocholesterolemic effect of blue-green alga, ishikurage (Nostoc commune) in rats fed atherogenic diet. Plant Food Hum Nutr. 1994; 45:63-70.

21. Huang H, Suo Y. Analysis and appraisal of the nutritive ingredient of Nostoc commune Vauch. Qinghai Science and Technology. 1999; 6:7-8.

22. Zhou S, Li T. Characteristic of the trace elements of Nostoc Commune in Qinghai Plateau. Guangdong Trace Elem Sci. 2001; 8:46-48.

23. Jaki B, Orjala J, Sticher O. A novel extracellular diterpenoid with antibacterial activity from the cyanobacterium Nostoc commune. J Nat Prod. 1999; 62:502-503.

24. Jaki B, Orjala J, Heilmann J, Linden A, Vogler B, Sticher O. Novel extracellular diterpenoids with biological activity from the cyanobacterium Nostoc commune. J Nat Prod. 2000; 63:339-343.

25. Jaki B, Heilmann J, Sticher O. New Antibacterial metabolites from the cyanobacterium Nostoc commune (EAWAG 122b). J Nat Prod. 2000; 63:1283-1285.

26. Arulselvan P, Fard MT, Tan WS, Gothai S, Fakurazi S, Norhaizan ME, Kumar SS. Role of antioxidants and natural products in inflammation. Oxid Med Cell Longev. 2016; 2016: 5276130.

27. Itoh T, Tsuchida A, Muramatsu Y, Ninomiya M, Ando M, Tsukamasa Y, Koketsu M. Antimicrobial and antiinflammatory properties of nostocionone isolated from Nostoc commune Vauch. and its derivatives against Propionibacterium acnes. Anaerobe. 2014; 27:56-63.

28. Niu L, Bi Y, Zhang S, Liu L. Study on antimicrobial capability of different solvent extracts from Nostoc commune Vauch. Sci Technol Food Ind. 2010; 31:68-70.

29. Qian S, Li R, Wei M, Yang C. Antimicrobial activities of extracts on several common microorganisms. Hunan Agricultural Sciences. 2011; 21:15-17.

30. Hameed M, Hassan S, Mohammed R, Gamal R. Isolation and characterization of antimicrobial active compounds from the cyanobacterium Nostoc commune Vauch. J Pure Appl Microbiol. 2013; 7:109-116.

31. Diao Y, Yang Z. Study on antibacterial effects of fat-souble compositions in Nostoc commune. Biotechnol Bull. 2014; 83-86.

32. Qian S, Li R, Wei M, Yang C. Extraction and antibacterial activity of polysaccharides from Nostoc commune. Food Sci. 2012; 33:96-99.

33. Kajiyama S, Kanzakti H, Kawazu K, Kobayashi A. Nostofungicidine, an antifungal lipopeptide from the field-grown terrestrial blue-green alga Nostoc commune. Tetrahedron Lett. 1998; 39:3737-3740.

34. Li R, Qian S, Dong Q, Liu H. Extraction of total flavonoids from Nostoc commune and preliminary determination of its antimicrobial effects. Acta Acad Med Wannan, 2012; 31:186-190.

35. Valko M, Leibfritz D, Moncol J, Cronin MT, Mazur M, Telser J. Free radicals and antioxidants in normal physiological functions and human disease. Int J Biochem Cell Biol. 2007; 39:44-84.
36. Rahman T, Hosen I, Islam MMT, Shekhar HU. Oxidative stress and human health. Adv Biosci Biotechnol. 2012; 03:997-1019.

37. Phaniendra A, Jestadi DB, Periyasamy L. Free radicals: properties, sources, targets, and their implication in various diseases. Indian J Clin Biochem. 2015; 30:11-26.

38. Ferrari C. Functional foods, herbs and nutraceuticals: towards biochemical mechanisms of healthy aging. Biogerontology. 2004; 5:275-289.

39. Lu J, Lin P, Yao Q, Chen C. Chemical and molecular mechanisms of antioxidants: experimental approaches and model systems. J Cell Mol Med. 2010; 14:840-860.

40. Wang H, Wu S, Liu D. Preparation of polysaccharides from cyanobacteria Nostoc commune and their antioxidant activities. Carbohydr Polym. 2014; 99:553-555.

41. Ninomiya M, Satoh H, Yamaguchi Y, Takenaka H, Koketsu M. Antioxidative activity and chemical constituents of edible terrestrial alga Nostoc commune Vauch. Biosci Biotechnol Biochem. 2011; 75:2175-2177.

42. Tang J, Hu Z. Radical scavenging activities of polysaccharides in three Nostoc species. J Wuhan Bot Res. 2006; 24:63-66.

43. Zhang W. Master thesis, Lanzhou University. 2007.

44. Ma W, Guo Y, Wei J. Preliminary discussions on free scavenging capacity of different extracts from Nostoc commune. Sci Technol Food Ind. 2009; 30:113-115.

45. Zhang T, Yang L, Liu Q, Wang Q, Xie Z, Li T. Antioxidant and antimicrobial activities of Nostoc commune polysaccharides. J Food Sci Biotechnol. 2011; 30:868-873.

46. Matsui K, Nazifi E, Hirai Y, Wada N, Matsugo S, Sakamoto T. The cyanobacterial UV-absorbing pigment scytonemin displays radical scavenging activity. J Gen Appl Microbiol. 2012; 58:137-144.

47. Diao Y, Yang Z. Antioxidant effects of crude fats in Nostoc commune. Biotechnol Bull. 2013; 68-72.

48. Diao Y. PhD thesis, University of Electronic Science and Technology of China, 2014.

49. Nazifi E, Wada N, Asano T, Nishiuchi T, Iwamuro Y, Chinaka S, Matsugo S, Sakamoto T. Characterization of the chemical diversity of glycosylated mycosporine-like amino acids in the terrestrial cyanobacterium Nostoc commune. J Photochem Photobiol B. 2015; 142:154-168.

50. Diao Y, Liu T, Han H. Study on FTIR and antioxidative activity of polysaccharides in Nostoc commune of different districts. Hubei Agr Sci. 2016; 55:984-996.

51. Fernández-García E. Skin protection against UV light by dietary antioxidants. Food Funct. 2014; 5:1994-2003.

52. Siegel RL, Miller KD, Jemal A. Cancer statistics, 2015. CA Cancer J Clin. 2015; 65:5-29.

53. Spano D, Heck C, De Antonellis P, Christofori G, Zollo M. Molecular networks that regulate cancer metastasis. Semin Cancer Biol. 2012; 22:234-249.

54. Marion D, Domanska U, Timmer-Bosscha H, Walenkamp A. Studying cancer metastasis: Existing models, challenges 
and future perspectives. Crit Rev Oncol Hematol. 2016; 97:107-117.

55. Guo S, Shan S, Jin X, Li Z, Song L, Li Z. Cloning and expression of a novel water stress protein from Nostoc commune Vauch. and its inhibitory effect on the proliferation of human colon cancer SW480 cells. Food Science, 2014; 35:151-155.

56. Guo S, Shan S, Jin X, Li Z, Li Z, Zhao L, An Q, Zhang W. Water stress proteins from Nostoc commune Vauch. exhibit anti-colon cancer activities in vitro and in vivo. J Agric Food Chem. 2015; 63:150-159.

57. Guo S, Guo X, Shan S, Wu H, Zhao L, Li Z. Effects of water stress proteins from Nostoc commune Vauch. on the cell adhesion of human colon cancer. J Shanxi Med Univ. 2015; 5:416-503.

58. Wang M, Gao Y, Xu D, Konishi T, Gao Q. Hericium erinaceus (Yamabushitake): a unique resource for developing functional foods and medicines. Food Funct. 2014; 5:3055-3064.

59. Huang $X$, Nie $S$. The structure of mushroom polysaccharides and their beneficial role in health. Food Funct. 2015; 6:3205-3217.

60. Guo M, Ding GB, Guo S, Li Z, Zhao L, Li K, Guo $\mathrm{X}$. Isolation and antitumor efficacy evaluation of a polysaccharide from Nostoc commune Vauch. Food Funct. 2015; 6:3035-3044.

61. Guo M, Ding GB, Yang P, Zhang L, Wu H, Li H, Li Z. Migration suppression of small cell lung cancer by polysaccharides from Nostoc commune Vaucher. J Agric Food Chem. 2016; 64:6277-6285.

62. Zong A, Cao H, Wang F. Anticancer polysaccharides from natural resources: a review of recent research. Carbohydr Polym. 2012; 90:1395-1410.

63. Locati M, Mantovani A, Sica A. Macrophage activation and polarization as an adaptive component of innate immunity. Adv Immunol. 2013; 120:163-184.

64. Jiang M, Zhu L, Jiang J. Immunoregulatory actions of polysaccharides from Chinese herbal medicine. Expert opin ther tar. 2010; 14:1367-1402.

65. Liao H, Wu T, Tai J, Chi M, Lin L. Immunomodulatory potential of the polysaccharide-rich extract from edible cyanobacterium Nostoc commune. Med Sci. 2015; 3:112-123.

66. Jensen S, Petersen B, Omarsdottir S, Paulsen B, Duus J, Olafsdottir E. Structural characterisation of a complex heteroglycan from the cyanobacterium Nostoc commune. Carbohydr Polym. 2013; 91:370-376. 